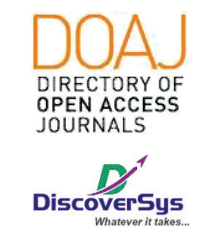

Published by DiscoverSys

\section{Peranan p53 dalam perkembangan dan prognosis osteosarkoma: tinjauan pustaka}

\author{
I Wayan Juli Sumadi, ${ }^{1 *}$ Nyoman Adiputra²
}

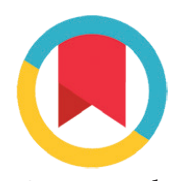

CrossMark

\title{
ABSTRACT
}

Background: Osteosarcoma is the most common non hematopoietic primary malignant tumor in the bone. Several factors have been related through the development and prognosis of osteosarcoma. One of them is the mutation of $p 53$ gene that encodes $p 53$ protein. This literature review aims to evaluate the role $\mathrm{p} 53$ in the progressiveness and prognosis of osteosarcoma.

Methods: A review of relevant literature was performed to elaborate p53 involvement in osetosarcoma. A total of 22 qualified published literature from 2006 until 2017 were collected from several electronic database as well as manual search and included in this review.

Results: P53 has an important role in maintaining genome integrity through its ability to induce genes involved in senescence process, DNA repair and apoptosis. Loss of P53 induces progenitor cells to proliferate and experience differentiation disturbances thereby increasing the potential malignant transformation to osteosarcoma. Loss of p53 also increases osteosarcoma progression by increasing proliferation and providing a good microenvironment for tumor cells. P53 causes inhibition to other tumor suppressor proteins such as BMP-2 and CD137L. Loss of P53 has a role in providing a good microenvironment for osteosarcoma cells to invade surrounding tissue, metastasis and suppressed immune response through increased activity of SDF-1, HIF-1a, VEGF, and N0. High mutant $\mathrm{p} 53$ expression has a positive association with shortterm survival but does not have a strong association to predict longterm survival.

Conclusion: A p53 gene has a pivotal role in the progressiveness and prognosis of osteosarcoma through increasing proliferation and providing a good microenvironment for tumor cells

Keywords: p53, osteosarcoma, progression, prognosis

Cite this Article: Sumadi, I.W.J., Adiputra, N. 2020. Peranan p53 dalam perkembangan dan prognosis osteosarkoma: tinjauan pustaka. Intisari Sains Medis 11(1): 41-46. D0I: 10.15562/ism.v11i1.536

\section{ABSTRAK}

Latar Belakang: Osteosarkoma merupakan tumor ganas primer non hematopoietik tersering pada tulang. Berbagai faktor telah dikaitkan dengan perkembangan dan prognosis pasien osteosarkoma, Salah satunya adalah mutasi gen $p 53$ yang menyandi protein $p 53$. Tinjauan pustaka ini bertujuan untuk mengevaluasi peran $\mathrm{p} 53$ dalam progresif dan prognosis osteosarkoma.

Metode: Tinjauan pustaka yang relevan dilakukan untuk menguraikan keterlibatan p53 dalam osetosarcoma. Sebanyak 22 literatur yang diterbitkan berkualitas dari 2006 hingga 2017 dikumpulkan dari beberapa basis data elektronik serta pencarian manual dan dimasukkan dalam ulasan ini.

Hasil: P53 mempunyai peranan yang sangat penting dalam menjaga integritas genom melalui kemampuannya untuk menginduksi gengen yang terlibat dalam proses penuaan sel, perbaikan DNA maupun apoptosis. Hilangnya p53 menginduksi sel-sel progenitor osteosarkoma untuk berproliferasi dan mengalami gangguan diferensiasi sehingga meningkatkan potensi transformasi keganasan menjadi osteosarkoma. Kehilangan p53 juga meningkatkan progresivitas osteosarkoma melalui peningkatan proliferasi dan penyediaan lingkungan mikro yang baik bagi sel tumor. P53 menyebabkan hambatan fungsi protein penekan tumor lainnya yaitu BMP-2 dan CD137L. Kehilangan p53 berperan dalam menyediakan lingkungan mikro yang baik untuk sel-sel osteosarkoma untuk menginvasi jaringan sekitar, bermetastasis dan menghambat aktivitas sistem imun melalui peningkatan aktivitas SDF-1, HIF-1a, VEGF, dan N0. Ekspresi p53 mutan yang tinggi memiliki hubungan positif dengan angka harapan hidup jangka pendek namun tidak memiliki hubungan yang kuat untuk memprediksi harapan hidup jangka panjang. Kesimpulan: Gen p53 memiliki peran penting dalam progresivitas dan prognosis osteosarkoma melalui peningkatan proliferasi dan menyediakan lingkungan mikro yang baik untuk sel tumor.
*Korespondensi:

I Wayan Juli Sumadi; Departemen Patologi Anatomi, Fakultas

Kedokteran Universitas Udayana,

RSUP Sanglah, Bali, Indonesia;

juli_sumadi@unud.ac.id
Kata Kunci: p53, osteosarkoma, progresivitas, prognosis

Cite Pasal Ini: Sumadi, I.W.J., Adiputra, N. 2020. Peranan p53 dalam perkembangan dan prognosis osteosarkoma: tinjauan pustaka. Intisari Sains Medis 11(1): 41-46. D0I: 10.15562/ism.v11i1.536

\section{PENDAHULUAN}

Osteosarkoma merupakan tumor ganas primer non hematopoietik tersering pada tulang. Osteosarkoma meliputi $20 \%$ dari keseluruhan tumor ganas primer tulang. Osteosarkoma memiliki puncak
Disetujui: $03-01$

Diterbitkan: 03-03-2020 
insiden yang bersifat bimodal, dimana $60 \%$ terjadi pada pasien berusia 15-25 tahun dan sisanya terjadi pada usia di atas 40 tahun. Tumor yang timbul pada usia tua seringkali terkait dengan Paget's disease. Osteosarkoma merupakan tumor ganas yang memiliki perjalanan klinis yang agresif dan dapat bermetastasis dengan cepat, terutama pada paru-paru. ${ }^{1}$

Dengan kemajuan kemoterapi saat ini, sekitar $70 \%$ pasien dengan osteosarkoma dapat bertahan cukup lama, namun pasien-pasien dengan metastasis jauh, memiliki angka harapan hidup lima tahun kurang dari $20 \%{ }^{2}$

Berbagai faktor telah dikaitkan dengan prognosis pasien dengan osteosarkoma, antara lain usia pasien, jenis kelamin, ukuran tumor, stadium saat terdiagnosis, loss of heterozygosity $(\mathrm{LOH})$ pada gen retinoblastoma, ekspresi HER2/erbB-2, dan kematian sel tumor pasca kemoterapi neoajuvan. Kematian sel tumor pasca kemoterapi neoajuvan yang diperiksa secara histologi dipercaya sebagai faktor prognosis yang penting, terutama pada osteosarkoma yang belum bermetastasis. ${ }^{2}$ Tumor nekrosis lebih dari 90\% pasca kemoterapi merupakan faktor prognosis yang penting secara klinis dan dikaitkan dengan angka harapan hidup 5 tahun lebih dari $80 \% .^{3}$

Selain faktor-faktor prognostik di atas, adanya mutasi gen TP53 sering dikaitkan dengan perkembangan dan prognosis osteosarkoma. Gen TP53 mengekspresikan protein $\mathrm{p} 53$ yang berperan sentral dalam monitoring stres dalam sel. Ia bisa teraktivasi oleh kondisi anoksia, adanya gangguan sinyal oleh onkoprotein yang mengalami mutasi, atau karena kerusakan DNA. Protein p53 mengontrol aktivitas protein yang terlibat pada penghentian siklus sel, perbaikan DNA, penuaan sel dan apoptosis. Gangguan pada ekspresi protein p53 sering dikaitkan dengan karsinogenesis berbagai keganasan pada manusia, termasuk osteosarkoma. ${ }^{4}$

Tulisan ini akan membahas lebih lanjut mengenai peranan p53 dalam menjaga integritas genom, peranan p53 dalam perkembangan osteosarkoma, dan p53 sebagai faktor prognosis osteosarkoma.

\section{PERANAN P53 DALAM MENJAGA INTEGRITAS GENOM}

Salah satu dari sifat khas sel kanker adalah memiliki sensitivitas yang rendah terhadap inhibisi pertumbuhan yang diperantarai oleh gangguan gen-gen penekan tumor. Salah satu gen penekan tumor yang sering ditemukan mengalami mutasi pada kanker manusia adalah gen TP53. Gen TP53 terletak pada kromosom 17p13.1 yang menyandi 393 asam amino protein p53. Fungsi utama dari protein p53 adalah menahan laju pembelahan sel dan menginduksi apoptosis sebagai respon terhadap kerusakan DNA. ${ }^{4}$

Mutasi TP53 sering ditemukan pada pasien sindroma Li-Fraumeni yang meningkatkan risiko untuk menderita kanker sebelum berusia 50 tahun sebesar 25 kali lipat dibandingkan orang normal. Jenis keganasan yang sering timbul pada sindroma ini adalah kanker payudara, leukemia, tumor otak, dan sarcoma terutama osteosarkoma., ${ }^{4,5}$

Selain akibat mutasi pada gen TP53, gangguan fungsi penekan siklus sel pada p53 juga dapat terjadi bila terdapat gangguan pada protein yang meregulasi p53. Misalnya, murine double minute 2 (MDM2) yang sering ditemukan mengalami overekspresi pada berbagai keganasan. Pada keadaan normal, kadar p53 di jaringan sulit dideteksi karena diikat oleh MDM2, namun bila sel mengalami stress onkogenik maka p53 akan dilepaskan oleh MDM2 melalui peningkatan protein p16 yang disandi oleh gen penekan tumor CDKN2A. Dalam suatu penelitian ditemukan bahwa inaktivasi p53 juga bisa disebabkan adanya hipermetilasi protein $\mathrm{H} 1 \mathrm{C} 1$ yang berfungsi memodulasi apoptosis tergantung p53. Inaktivasi HIC1 berakibat pada peningkatan SIRT1 deacetylase yang kemudian menginaktivasi p53. ${ }^{6,7}$

Aktivasi p53 oleh stress sel akibat kerusakan DNA atau kondisi hipoksia akan menyebabkan penghentian siklus sel pada fase G1. Protein p53 akan menginduksi perbaikan DNA melalui peningkatan ekspresi protein P21, suatu protein penghambat kinase tergantung cyclin yang dikode oleh gen CDKN1A dan GADD45. ${ }^{4}$ Apabila perbaikan DNA berhasil, maka siklus sel dapat dilanjutkan ke fase berikutnya, namun jika gagal maka p53 akan mengarahkan sel untuk masuk ke jalur apoptosis atau jalur penuaan sel. Apabila suatu sel memiliki gangguan fungsi p53 atau terjadi mutasi gen TP53 maka penghentian siklus sel akan terganggu, sehingga sel dengan gangguan genetik tersebut akan terus berproliferasi meningkatkan kemungkinan terjadinya keganasan. ${ }^{4}$

\section{PERANAN P53 DALAM PERKEMBANGAN OSTEOSARKOMA}

Meskipun pada pasien osteosarkoma seringkali ditemukan adanya mutasi $p 53$, namun peranannya dalam osteosarkomagenesis belum dipahami secara detail. Adanya mutasi pada gen $p 53$ dan gen $R B$ tampaknya menjadi penyebab dominan timbulnya osteosarkoma. ${ }^{5,8}$ Osteosarkoma seringkali terjadi pada pasien dengan sindroma Li-Fraumeni dan pasien retinoblastoma herediter. Pasien dengan sindroma Li-Fraumeni telah diketahui memiliki mutasi pada satu alel gen p53, sehingga mutasi $p 53$ dikaitkan sebagai faktor penyebab osteosarkoma. ${ }^{4}$ 
Hilangnya fungsi p53 normal menyebabkan menurunnya hambatan terhadap siklus sel dan menurunya apoptosis sehingga meningkatkan kemampuan proliferasi sel tumor pada osteosarkoma. Suatu penelitian yang menggunakan hewan coba dengan delesi terbatas p53 dan pRb pada sel osteoblasnya mendapatkan bahwa pertumbuhan osteosarkoma tampaknya bersifat dependen terhadap hilangnya p53 dan dipotensiasi oleh hilangnya $\mathrm{pRb}$. Model hewan coba tersebut juga menunjukkan berbagai gambaran yang mirip dengan osteosarkoma pada manusia, termasuk kompleksitas sitogenetik dan ekspresi gen, gambaran histologi maupun perilaku metastasisnya. Pada penelitian ini juga dilakukan pemeriksaan penanda progenitor osteoblas (Runx2, Osterix), preosteoblas (alkaline phosphatase, Collagen1a1, Ebf2, BMP4), dan osteoblas matur (osteoprotegerin, bone sialoprotein, osteocalcin) menggunakan quantitative realtime PCR. Murine osteosarkoma cell lines tampak mengekspresikan penanda progenitor osteoblas dan preosteoblas, namun tidak mengekspresikan penanda osteoblas yang matur. Hal ini menandakan bahwa murine osteosarkoma cell lines berhenti pada tahap diferensiasi preosteoblas. ${ }^{8}$

Penelitian lainnya juga mendukung peranan hilangnya p53 dalam karsinogenesis osteosarkoma.

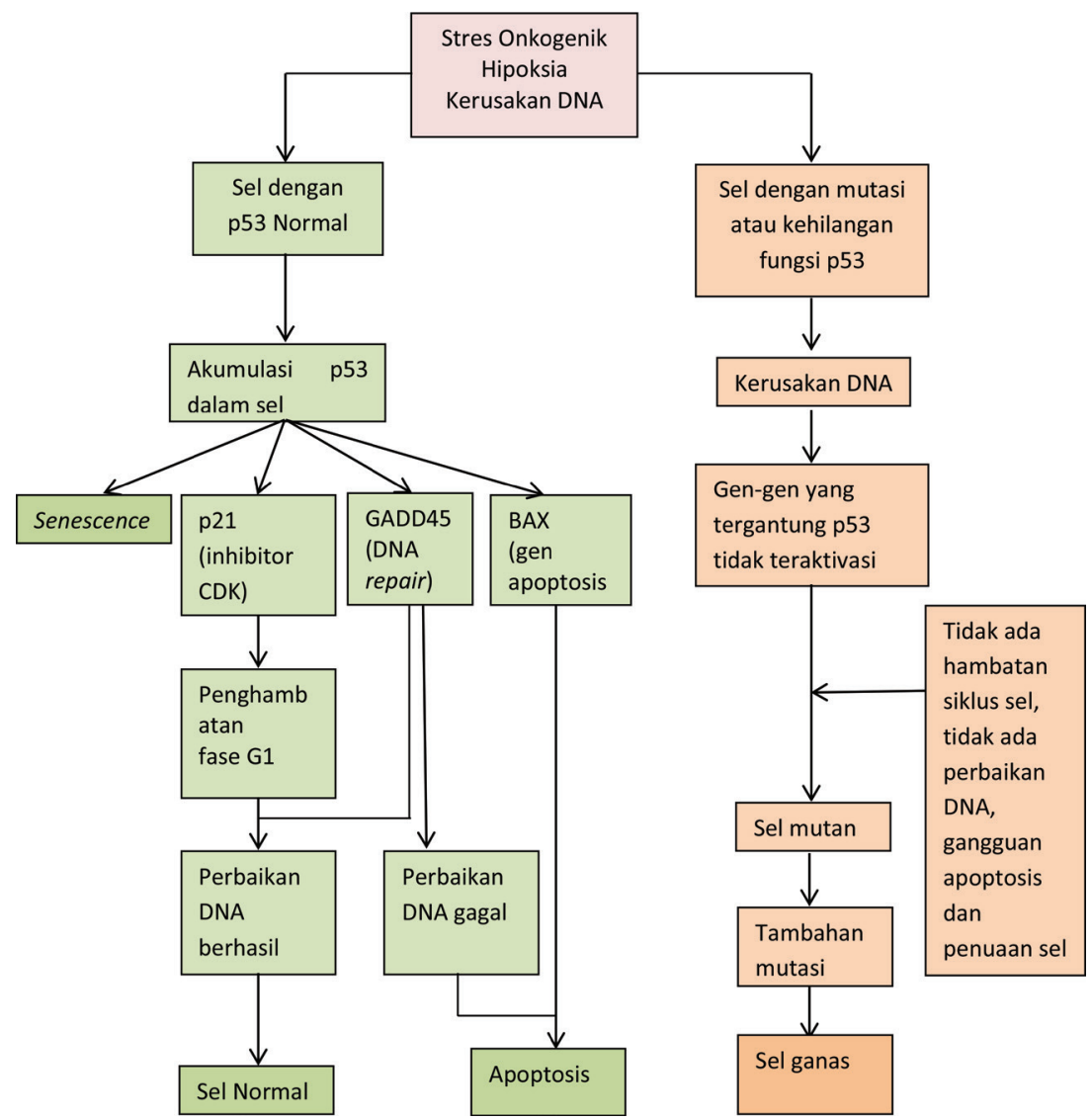

Gambar 1 Gambar skematik yang menjelaskan peran p53 dalam menjaga integritas genom ${ }^{4}$
Defisiensi fungsi p53 saja atau dengan kombinasi hilangnya $\mathrm{Rb}$ pada mesenchymal stem/stromal cells (MSCs) menginduksi terjadinya sarcoma invivo. Inaktivasi $\mathrm{Rb}$ dan $\mathrm{p} 53$ pada sel-sel progenitor osteogenik yang berasal dari sumsum tulang menyebabkannya berkembang menjadi osteosarkoma-like tumor. ${ }^{9}$

Protein p53 memiliki kemampuan meregulasi mesenchymal stromal cells (MSCs). MSCs dengan wild type p53 menghambat diferensiasi osteogenik melalui hambatan terhadap Runx2, suatu faktor transkripsi yang diperlukan dalam diferensiasi osteogenic MSCs. Sedangkan pada MSCs dengan delesi p53 terjadi peningkatan kadar Runx2 dan peningkatan proliferasi dan diferensiasi osteogenik. Hal ini mengindikasikan bahwa BMSCs yang kehilangan p53 lebih memungkinkan untuk berkembang menjadi osteosarkoma dibandingkan dengan BMCs yang memiliki wild-type p53. Protein p53 juga memiliki kemampuan menghambat proliferasi dan meningkatkan apoptosis pada sel-sel osteosarkoma melalui aktivasi BMP-2, suatu protein yang berperan penting dalam diferensiasi dan penghambatan proliferasi sel tulang. ${ }^{5}$ Kehilangan p53 pada MSCs juga menyebabkan penurunan respon terapi terhadap antikanker. Hal ini terjadi akibat kegagalan aktivasi gen-gen yang diinduksi p53 dan kegagalan induksi apoptosis oleh sel tumor. ${ }^{10}$

Pada suatu penelitian yang menggunakan tikus coba berhasil teridentifikasi 3 gen yang merupakan target langsung gen p53 yaitu CD137L, CDC42 binding protein kinase gamma dan Follistatin, yang memiliki efek penekanan pertumbuhan pada osteosarcoma cell lines. Di antara 3 gen target tersebut, hanya gen $C D 137 L$ yang menyandi molekul kostimulator Cd137l yang terinduksi secara invivo pada tulang calvaria tikus coba. Sel-sel yang mengekspresikan CD137L menunjukkan efek penghambatan pertumbuhan secara invivo. Fusi segmen Fc protein Cd137L juga mengaktivasi respon imun in vitro melalui aktivasi limfosit $\mathrm{T}$ dan menahan laju pertumbuhan sel osteosarkoma in vitro. Hasil ini menunjukkan peranan CD137L sebagai target p53 dalam osteosarkomatogenesis dan memiliki peranan dalam regulasi respon imun melalui p53. ${ }^{11}$

Mesenchymal stromal cells (MSCs) yang kehilangan p53 menunjukkan sifat yang membantu pertumbuhan sel tumor, dimana ia mensekresi nitric oxide (NO) yang lebih tinggi dibandingkan dengan MSCs yang memiliki wild-type p53. Sekresi NO yang tinggi dapat menghambat proliferasi, menghambat sekresi sitokin dan menginduksi apoptosis sel limfosit $\mathrm{T}$ sehingga memudahkan sel tumor untuk tumbuh dan berproliferasi. ${ }^{12}$ Dengan demikian, mutasi p53 juga dapat meningkatkan progresifitas osteosarkoma melalui hambatan terhadap aktivitas sistem imun. 
Protein p53 juga memiliki peranan penting dalam menyiapkan lingkungan mikro yang baik untuk perkembangan dan progresivitas osteosarkoma. p53 dapat menekan produksi kemokin stromal cell-derived factor-1 (SDF-1) pada kultur sel fibroblas, hal ini terjadi melalui penekanan ekspresi mRNA SDF-1 oleh p53. Stromal cell-derived factor-1 dapat memacu migrasi dan meningkatkan kemampuan invasif sel-sel tumor yang mengekspresikan reseptor CXCR4, sehingga pada keadaan dimana terjadi penurunan fungsi p53 maka akan memudahkan sel-sel tumor bermetastasis. ${ }^{13}$

Tidak adanya 533 pada stroma memudahkan sel tumor untuk bermetastasis karena akan meningkatkan ekspresi hypoxia inducible factor-1 alpha (HIF-1 alfa) pada keadaan hipoksia sel tumor. Peningkatan HIF-1 alfa akan meningkatkan ekskresi vascular endothelial growth factor (VEGF) oleh sel tumor sehingga terjadi peningkatan angiogenesis, neovaskularisasi dan memudahkan invasi sel tumor ke pembuluh darah yang berujung pada metastasis jauh. ${ }^{14}$ Adapun ringkasan gambar skematik yang menjelaskan peran p53 dalam menjaga integritas genom dapat dilihat pada Gambar 1.

\section{Gen p53 Sebagai Penanda Prognosis Osteosarkoma}

Hingga saat ini, telah terdapat berbagai penelitian yang menilai peranan p53 dalam memprediksi luaran pasien-pasien dengan osteosarkoma dengan hasil yang tidak konsisten. Pada penelitian oleh Park et al. yang meneliti perbedaan ekspresi p53 mutan pada low grade osteosarkoma dan high grade osteosarkoma mendapatkan bahwa ekspresi p53 mutan pada low grade osteosarkoma lebih tinggi dibandingkan dengan high grade osteosarkoma yang memiliki prognosis yang lebih buruk. MDM-2 diduga terlibat dalam tumorigenesis low grade osteosarkoma karena sangat sedikit kasus yang mengekspresikan p53 mutan namun belum diperiksa pada penelitian ini. ${ }^{15}$

Dalam suatu penelitian yang melibatkan 201 pasien osteosarkoma menemukan bahwa polimorfisme pada gen TP53 (TP53Arg72Pro polymorphism) memiliki nilai prognosis dalam meramalkan angka harapan hidup pasien dengan osteosarkoma. Pasien dengan polimorfisme gen TP53 memiliki risiko kematian yang meningkat. Polimorfisme gen TP53 juga merupakan penanda independen untuk overall survival pada pasien high-grade osteosarkoma yang mendapatkan kemoterapi neoajuvan, namun tidak berkaitan dengan gambaran histopatologik osteosarkoma, stadium, lokasi tumor maupun nekrosis sel tumor pasca kemoterapi. ${ }^{16}$ Hasil yang konsisten juga ditemukan oleh Boulytcheva et al. yang mendapatkan bahwa ekspresi p53 mutan yang tinggi mempunyai korelasi yang sanagat bermakna dengan overall survival (OS) pasien yang buruk. ${ }^{17}$

Pada penelitian lain yang mempelajari hubungan ekspresi protein apoptosis, yakni p53, c-MYC, BCL-2 dan indeks apoptosis dengan klasifikasi patologik dan prognosis osteosarkoma mendapatkan bahwa ekspresi p53, c-MYC, dan BCL-2 memilki hubungan negatif dengan indeks apoptosis dan berkaitan erat dengan prognosis osteosarkoma namun tidak memiliki hubungan dengan klasifikasi patologik dari osteosarkoma. Ekspresi p53 pada pasien-pasien osteosarkoma yang bertahan hidup lebih dari 3 tahun ditemukan lebih rendah dibandingkan pasien yang bertahan hidup kurang dari 3 tahun. Sementara itu, ekspresi protein regulator apoptosis lainnya, yakni C-MYC dan ekspresi BCL-2 juga ditemukan lebih rendah pada kelompok pertama. ${ }^{18}$

Salah satu peranan p53 adalah meregulasi apoptosis. Dengan mengamati apoptosis secara tidak langsung dapat memprediksi fungsi dari p53 pada suatu keganasan. Wu et al., dalam penelitiannya menemukan bahwa index apoptosis yang tinggi berhubungan erat dengan prognosis osteosarkoma yang baik dimana angka harapan hidupnya lebih baik, namun index apoptosis ini tidak berhubungan dengan stadium. Index apoptosis pasien dengan angka harapan hidup $>5$ tahun secara statistik lebih tinggi dibandingkan dengan index apoptosis pasien-pasien dengan harapan hidup $\leq 5$ tahun. ${ }^{19}$

P53 sebagai penanda biologik yang efektif dalam memprediksi prognosis pasien-pasien dengan osteosarkoma juga didukung oleh suatu meta-analisis yang dilakukan oleh Hai-Liang $\mathrm{Fu}$, et al. Pada studi yang melibatkan total 609 pasien osteosarkoma tersebut didapatkan bahwa pasien-pasien dengan ekspresi p53 yang tinggi memiliki angka harapan hidup 3 tahun yang lebih rendah dibandingkan dengan pasien osteosarkoma dengan ekspresi p53 yang rendah. Ekspresi p53 juga didapatkan berhubungan erat dengan penurunan DFS dan OS pasien osteosarkoma. ${ }^{20}$

Hal ini didukung pula oleh penelitan Jiang, et al. yang menilai hubungan ekspresi p53 dengan OS dan DFS pada pasien dengan tumor ganas tulang. Penelitian ini mendapatkan bahwa ekspresi p53 yang tinggi dapat memprediksi OS dan DFS yang buruk pada seluruh pasien tumor ganas tulang. Secara khusus, ekspresi p53 berhubungan erat dengan OS dan DFS yang buruk pada pasien osteosarkoma dan Ewing Sarcoma. ${ }^{21}$

Sementara itu, pada penelitian meta-analysis lainnya didapatkan hasil yang sedikit berbeda, dimana kelainan pada p53, baik itu overekspresi protein $\mathrm{p} 53$ yang dideteksi dengan metode imunohistokimia maupun mutasi gen $p 53$ yang dideteksi 


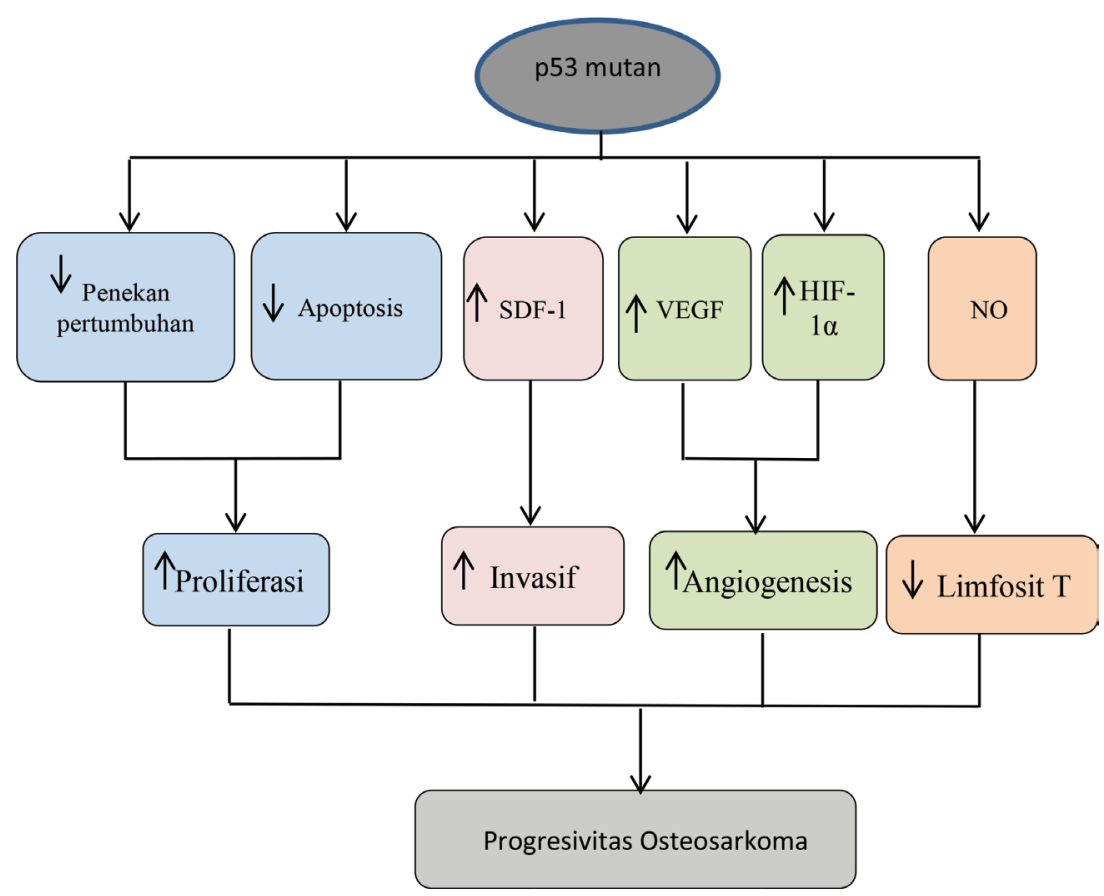

Gambar 2 Peranan p53 dalam progresivitas osteosarkoma. Adanya mutasi p53 menyebabkan peningkatan kemampuan proliferasi sel tumor osteosarkoma melalui hambatan terhadap penekan pertumbuhan dan penurunan aktivitas apoptosis; meningkatnya kemampuan invasi sel tumor; meningkatnya kemampuan angiogenesis; dan penurunan fungsi limfosit $\mathrm{T}$ yang semuanya berujung pada peningkatan progresivitas osteosarkoma

dengan RT-PCR berhubungan erat dengan angka harapan hidup 2 tahun yang buruk, terutama pada kelompok deteksi mutasi gen p53 dengan RT-PCR, namun hal ini tidak memiliki hubungan dengan angka harapan hidup 3 tahun dan 5 tahun. Data ini menandakan bahwa adanya kelainan pada p53 hanya bisa digunakan sebagai penanda prognosis jangka pendek saja. Selain itu, ekspresi p53 memiliki hubungan yang lebih kuat dengan angka harapan hidup 2 tahun pada pasien-pasien osteosarkoma yang mendapatkan terapi neoajuvan kemoterapi dan pembedahan dibandingkan dengan pasien-pasien yang hanya diterapi dengan pembedahan saja. ${ }^{22}$ Adapun ringkasan peranan p53 dalam progresivitas osteosarcoma dapat dilihat pada Gambar 2.

\section{KESIMPULAN}

P53 mempunyai peranan yang sangat penting dalam menjaga integritas genom melalui kemampuannya untuk menginduksi gen-gen yang terlibat dalam proses penuaan sel, perbaikan DNA maupun menginduksi proses apoptosis melalui jalur intrinsik. Ketiadaan p53 baik karena mutasi gen TP53 maupun karena gangguan fungsi p53 menyebabkan integritas genom sel tidak terjaga dan meningkatkan risiko keganasan. Kombinasi hilangnya p53 dan $\mathrm{Rb}$ menginduksi sel-sel progenitor osteosarkoma untuk berproliferasi dan mengalami gangguan diferensiasi sehingga meningkatkan potensi transformasi keganasan menjadi osteosarkoma. Penurunan p53 juga menyebabkan hambatan fungsi protein penekan tumor lainnya yaitu BMP-2 dan CD137L. Kehilangan p53 juga berperan dalam menyediakan lingkungan mikro yang baik untuk sel-sel osteosarkoma untuk menginvasi jaringan sekitar, bermetastasis, dan menekan sistem imun melalui peningkatan aktivitas SDF-1, HIF-1a, VEGF, dan NO. Berbagai penelitian yang menghubungan mutasi p53 dengan prognosis pasien osteosarkoma memberikan hasil yang kurang konsisten untuk memprediksi prognosis jangka panjang meskipun sebagian besar mendapatkan hasil bahwa ekspresi p53 yang tinggi dapat memprediksi prognosis dalam jangka pendek.

\section{KONFLIK KEPENTINGAN}

Tidak terdapat konflik kepentingan dalam penulisan tinjauan kepustakaan ini.

\section{PENDANAAN}

Tidak ada.

\section{KONTRIBUSI PENULIS}

Seluruh penulis memiliki kontribusi yang sama dalam penulisan tinjauan kepustakaan ini baik dari tahap penyusunan kerangka konsep, pencarian literatur yang relevan, pengumpulan data, hingga analisis dan sintesis tinjauan kepustakaan dalam bentuk narasi yang logis dan sistematis.

\section{DAFTAR PUSTAKA}

1. Picci P. Osteosarcoma (Osteogenic sarcoma). Orphanet J Rare Dis. 2007;2:6.

2. Fletcher CDM, Bridge JA, Hogendoorn PCW, Mertens F. WHO Classification of Tumours of Soft Tissue and Bone. Lyon: IARC; 2013.

3. Folpe AL, Inwards CY. Bone and Soft Tissue Pathology. Philadelphia: Elsevier Saunders; 2010.

4. Kumar V, Abbas AK, Aster JC. Robbins and Cotran Pathologic Basis of Disease. $9^{\text {th }}$ ed. Philadelphia: Saunders Elsevier; 2015.

5. Velletri T, Xie N, Wang Y, Huang Y, Yang Q, Chen X, et al. P53 functional abnormality in mesenchymal stem cells promotes osteosarcoma development. Cell Death Dis. 2016;7:e2015.

6. Rao-bindal K, Kleinerman ES. Epigenetic Regulation of apoptosis and cell cycle in osteosarcoma. Sarcoma. 2011;2011:679457.

7. Wang L, Liu Z, Jing P, Shao L, Chen L, He X, et al. Effects of murine double minute 2 polymorphisms on the risk and survival of osteosarcoma: a systemic review and meta-analysis. Tumour Biol. 2014;35(2):1649-52. 
8. Walkley CR, Qudsi R, Sankaran VG, Perry JA, Gostissa M, Roth SI, et al. Conditional mouse osteosarcoma, dependent on $\mathrm{p} 53$ loss and potentiated by loss of Rb, mimics the human disease. Genes Dev. 2008:22(12);1662-76.

9. Rubio R, Gutierrez-Aranda I, Sáez-Castillo AI, Labarga A, Rosu-Myles M, Gonzalez-Garcia S, et al. The differentiation stage of p53-Rb-deficient bone marrow mesenchymal stem cells imposes the phenotype of in vivo sarcoma development. Oncogene. 2012;32(41):4970-80.

10. Dudley AC, Shih SC, Cliffe AR, Hida K, Klagsbrun M. Attenuated p53 activation in tumour-associated stromal cells accompanies decreased sensitivity to etoposide and vincristine. Br J Cancer. 2008;99(1):118-125.

11. Tsuda Y, Tanikawa C, Miyamoto T, Hirata M, Yodsurang V, Zhang YZ, et al. Identification of a p53 target, CD137L, that mediates growth suppression and immune response of osteosarcoma cells. Sci Rep. 2017;7(1):10739.

12. Huang Y, Yu P, Li W, Ren G, Roberts AI, Cao W, et al. p53 regulates mesenchymal stem cell-mediated tumor suppression in a tumor microenvironment through immune modulation. Oncogene. 2014;33(29):3830-3838.

13. Moskovits N, Kalinkovich A, Bar J, Lapidot T, Oren M. p53 Attenuates Cancer cell migration and invasion through repression of SDF-1 / CXCL12 Expression in stromal fibroblasts. Cancer Res. 2006;66(22):10671-6

14. Ren H, Zhang Y, Li H, Xie T, Sun L, Zhu T, et al. Prognostic role of hypoxia-inducible factor- 1 alpha expression in osteosarcoma: a meta-analysis. Onco Targets Ther. 2016;9:1477-1487

15. Coimbra IB, Jimenez SA, Hawkins DF, Piera-Velazquez S, Stokes DG. Hypoxia inducible factor- 1 alpha expression in human normal and osteoarthritic chondrocytes. Osteoarthritis Cartilage. 2004;12(4):336-45.
16. Toffoli G, Biason P, Russo A, De Mattia E, Cecchin E, Hattinger CM, et al. Effect of TP53 Arg72Pro and MDM2 SNP309 polymorphisms on the risk of high-grade osteosarcoma development and survival. Clin Cancer Res. 2009;15(10):3550-6.

17. Boulytcheva IV, Soloviev YN, Kushlinskii NE, Mahson AN. Expression of Molecular Markers in the Tumor and Survival Prognosis in Osteosarcoma. Bull Exp Biol Med. 2010;150(2):237-42.

18. Wu X, Cai ZD, Lou LM, Zhu YB. Expressions of p53, c-MYC, BCL-2 and apoptotic index in human osteosarcoma and their correlations with prognosis of patients. Cancer Epidemiol. 2012;36(2):212-6.

19. Wu X, Cheng B, Cai ZD, Lou LM. Determination of the apoptotic index in osteosarcoma tissue and its relationship with patients prognosis. Cancer Cell Int. 2013;13(1):56.

20. Fu HL, Shao L, Wang Q, Jia T, Li M, Yang DP. A systematic review of p53 as a biomarker of survival in patients with osteosarcoma. Tumor Biol. 2013;34(6):3817-21.

21. Jiang $\mathrm{L}$, Tao $\mathrm{C}, \mathrm{He}$ A. Prognostic significance of $\mathrm{p} 53$ expression in malignant bone tumors: a meta-analysis. Tumor Biology. 2013;34(2):1037-43.

22. Yao D, Cai G, Chen J, Ling R, Wu S, Li Y. Prognostic value of p53 alterations in human osteosarcoma: a meta analysis. 2014;7(10):6725-33.

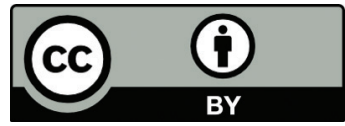

This work is licensed under a Creative Commons Attribution 